\title{
Progression in the bacterial load during the breeding season in nest boxes occupied by the Blue Tit and its potential impact on hatching or fledging success
}

\author{
Andrew Devaynes $^{1}$ (D) André Antunes ${ }^{1} \cdot$ Alan Bedford $^{1} \cdot$ Paul Ashton $^{1}$
}

Received: 15 January 2018 / Revised: 22 May 2018 / Accepted: 18 June 2018 / Published online: 28 June 2018

(c) The Author(s) 2018

\begin{abstract}
The Blue Tit Cyanistes caeruleus prefer to use nest boxes to raise their young rather than nests in natural tree cavities. However, nest boxes provide a warm, humid microclimate that is favourable to the growth of rich bacterial communities. In this study we investigated how the bacterial community developed throughout the breeding season and whether it had any effect on egg or nestling mortality. Samples were collected across six sites and three breeding seasons at the completion of nest building, clutch completion and immediately post fledging. Bacterial counts were obtained for each sample, including a total bacterial count using non-selective media and bacterial counts on selective media for Staphylococcus spp. and Enterobacter spp, which may indicate pathogenicity to the birds. There were significantly more bacteria (total counts and counts for Staphylococcus spp. and Enterobacter spp. specifically) present within the nest box at the post fledging stage compared to the two earlier stages, likely due to increased activity by the adult birds (feeding of the nestlings and defecating) and less time by the adult birds for self-preening and nest sanitation. No positive relationship was found between bacterial counts and either egg mortality, nestling mortality or brood size; however, a negative relationship between egg mortality and total bacterial count was identified. Although somewhat unexpected, this negative relationship may indicate the presence of a greater number of symbiotic bacteria, which could offer a greater level of protection.
\end{abstract}

Keywords Bacteria $\cdot$ Birds $\cdot$ Nest $\cdot$ Breeding $\cdot$ Success

\section{Zusammenfassung}

Wachsende Belastung durch Bakterien in Nistkästen von Blaumeisen während der Brutzeit und ihr möglicher Einfluss auf Schlüpfen und Flüggewerden

Blaumeisen (Cyanistes caeruleus) ziehen für die Aufzucht ihrer Jungen Nistkästen den natürlichen Baumhöhlen vor. Aber die Nistkästen bieten ein warmes und feuchtes Mikroklima, das die Entwicklung von Bakteriengemeinschaften fördert. In dieser Studie wurde untersucht, wie sich die Bakteriengemeinschaften während der Brutzeit entwickelten und ob sie einen Einfluss auf die Sterberate der Nestlinge oder das Absterben der Eier hatten. Über drei Brutzeiten und sechs Brutplätze hinweg wurden während des Nestbaus, der Vervollständigung des Geleges und unmittelbar nach Ausfliegen der Jungen Proben gesammelt und für jede Probe die darin enthaltenen Bakterien gezählt. Zum einen wurde mit unspezifischen Nährmedien die Gesamtzahl ermittelt, zum anderen anhand von spezifischen Medien die Anzahl von Staphylococcus spp. und von Enterobacter spp., die beide als Hinweis auf bakterielle Pathogenität für die Vögel genommen werden können. Nach dem Ausfliegen gab es in den Nistkästen signifikant mehr Bakterien (insgesamt, sowie auch Staphylococcus spp. und Enterobacter spp.), vermutlich wegen der erhöhten Aktivität für das Füttern der Jungen und Entfernen der Kotballen und der entsprechend weniger verfügbaren Zeit für das Putzen der Nester und der Adulten selbst. Ein positiver Zusammenhang mit der Gelegegröße oder der Sterberate von Nestlingen oder Eiern konnte nicht festgestellt werden, wohl aber eine negative Beziehung zwischen der Gesamtzahl an Bakterien und der Absterberate der Eier. Obwohl etwas unerwartet, könnte dies ein Hinweis auf eine größere Anzahl symbiontischer Bakterien sein, die möglicherweise einen größeren Schutz bieten.

Communicated by K. C. Klasing.

Extended author information available on the last page of the article 


\section{Introduction}

Nesting birds face many potential threats to breeding success, among which predation and adverse weather are major factors considered when choosing a nesting site. Breeding success is subject to a high selection pressure and therefore plays an important role in determining the evolution of life history traits of birds, especially behaviour within the nest, including nest site selection, nest material selection and incubation behaviour (Peralta-Sanchez et al. 2012). Hole-nesting birds prefer to use human-placed nest boxes when available as these are sturdier and offer greater protection than natural tree cavities (Goodenough and Hart 2011). Birds using natural tree cavities suffer higher losses to predation, soaking and predation of adults on the nest (Wesolowski and Rowinski 2012).

Studies have shown that nest boxes for Cyanistes caeruleus (Blue Tit; Moreno et al. 2009; Hebda and Wesolowski 2012), Parus major (Great Tit; Hebda and Wesolowski 2012), Sturnus vulgaris (European Starling; Gwinner and Berger 2005), Tachycineta bicolor (Tree Swallow; Dawson 2004) and Ficedula hypoleuca (Pied Flycatcher; Moreno et al. 2009) harbour significantly higher loads of ectoparasites than natural nests in tree cavities. It can therefore be concluded that the issue of high ectoparasite loads in nest boxes (mainly fleas, mites and blowfly larvae) is associated with the nest box itself rather than with an individual species. Consequently, nest re-use is rare, and most birds will construct a new nest for each breeding attempt to reduce the likelihood of exposing themselves, their eggs and their nestlings to ectoparasites and potentially rich bacterial communities (Newton 1994). However, for cavity-nesting passerines, nest site availability is the main factor constraining reproduction, resulting in the potential re-use of old nest boxes.

While ectoparasites have been studied in relative detail, little attention has been paid to the bacterial loads of the nest box despite the possibility of these loads being pathogenic agents and the nest box providing favourable conditions for the growth of bacterial communities given their stable microclimatic conditions (Gonzalez-Braojos et al. 2012a).

Bacteria within the nest originate from the nesting material, food items and the adult birds themselves (Mills et al. 1999), with the adult birds playing host to a community of bacteria in their plumage. These bacteria can be separated into two ecological classes: free-living and attached. Free-living bacteria are labile while attached bacteria represent a much more stable community. Bacteria attached to the plumage can be a problem for the bird itself, as certain bacterial species are capable of degrading $\beta$-keratin, the major component (>90\%) of feathers (Alt et al. 2015). In relation to nest re-use Gonzalez-Braojos et al. (2012b) found $F$. hypoleuca nestlings raised in old, reused nests harboured higher bacterial loads on their belly skin than those reared in freshly built nests. Bacteria can also be transmitted onto the egg shell where it can penetrate through pores and infect the embryo, thereby reducing hatching success (Soler et al. 2012). Increased bacterial abundance transmitted to the egg shell increases the chances of embryo infection. Pinowski et al. (1994) found that Passer domesticus and P. montanus eggs which had failed to hatch were infected with Escherichia coli and Staphylococcus epidermitis. These findings suggest that selection should favour birds who attempt to limit the bacterial load of their plumage to control potential contamination (Shawkey et al. 2009). One method exercised by birds to control plumage bacteria is self-preening. Preening stimulates the secretion of uropygial oil which contains beneficial, symbiotic bacteria that can control the load of pathogenic, feather-degrading bacterial species (Soler et al. 2008; Martin-Vivaldi et al. 2009). However, preening is a time-consuming process and during the breeding season there is a trade-off between preening and parental effort (Lucas et al. 2005). This trade-off leads to an increased abundance of free-living bacteria within the plumage and thus an increased likelihood of the bacteria being transmitted onto the egg (Alt et al. 2015).

Upon hatching, nestlings are essentially sterile but are quickly colonised by bacteria from the nesting material, food items and adult birds (Mills et al. 1999). The colonising bacteria may be commensal or indeed symbiotic, aiding in food digestion and complementing the immune system. However, some bacteria may be pathogenic, with the ability to affect the growth and survival of altricial nestlings. Feather-degrading bacteria can be transmitted to nestlings, which can lead to problems with thermoregulation (Ichida et al. 2001) and flight efficiency (Moller et al. 2012) and alterations to plumage colour that can affect feather-based communication (Kilgas et al. 2012). Larger broods equate to higher parental intensity and reduced nest and self-sanitation (Cantarero et al. 2013) and correlate with increased bacterial loads (Gonzalez-Braojos et al. 2012b, 2015). Alt et al. (2015) found female $F$. hypoleuca with experimentally reduced broods had the lowest number of free-living bacteria on their feathers; conversely, females with the male experimentally removed and therefore unable to assist in feeding the nestlings had the highest. Nestling fecal sacs have a mucous coating encasing the fecal bacteria; however, the mucous covering only offers protection for $23 \mathrm{~min}$ (Ibanez-Alamo et al. 2014) and given the increased workload of the female they can rarely be removed within this time period. In a similar study on S. vulgaris, Lucas et al. (2005) also discovered an increase in free-living bacteria but did not observe any change in the attached bacterial community. 
Of the few studies conducted to date with the aim to identify bacteria within a nest box, Goodenough and Stallwood discovered 32 species (Goodenough and Stallwood 2010) and 28 species (Goodenough and Stallwood 2012) of bacteria associated with $C$. caeruleus and $P$. major, respectively. Of the bacteria found, Enterobacter cloacae and Staphylococcus hyicus were found to be negatively associated with fledging success. Berger et al. (2003) identified 12 genera of bacteria in the nests of $S$. vulgaris, of which Klebsiella sp. and Enterococcus sp. were the most prevalent. Of the bacteria identified, the authors could not determine pathogenicity because the bacterial load was not calculated. It is known that bacterial species which may be part of the normal microbial flora and be beneficial can become pathogenic to the host when there is a considerable increase in their numbers. Studies which have investigated the bacterial loads of nest boxes have only sampled at a single point when nestlings were present in the nest, with the exception of Gonzalez-Braojos et al. (2012a, 2015), who sampled $F$. hypoleuca nests at days 7 and 13 post hatching, and Gwinner and Berger (2005), who sampled S. vulgaris nests at days 1,9 and 14 post hatching. Few studies have investigated the bacterial load prior to hatching, despite bacteria being closely linked with embryo fatality (Soler et al. 2012). Thus, we decided to address some of these gaps in the literature by investigating bacterial community development in $C$. caeruleus nest boxes during the breeding season and the impact, if any, of changes in the bacterial community on the breeding attempt.

Cyanistes caeruleus is a suitable model organism as the birds of this species readily accept the shelter of a nest box, occupying up to two-thirds of those available at study sites (personal observation of authors). There are 20-44 million breeding pairs in Europe (Royal Society for the Protection of Birds 2016), and the species is classified as being of "least concern" on the International Union for Conservation of Nature (IUCN) Red List of Threatened Species, showing an increasing trend in population numbers (IUCN 2016). The aims of our study were to discover: (1) the bacterial load of the nest box at nest building, once eggs are present and immediately post fledging, (2) any relationship between the bacterial count at clutch completion and egg mortality, (3) any relationship between the bacterial load immediately post fledging and chick mortality and (4) any relationship between bacterial load and brood size in $C$. caeruleus.

\section{Methods}

\section{Study sites}

The study was performed during the breeding seasons of 2014, 2015 and 2016 across six sites. Most of the study sites

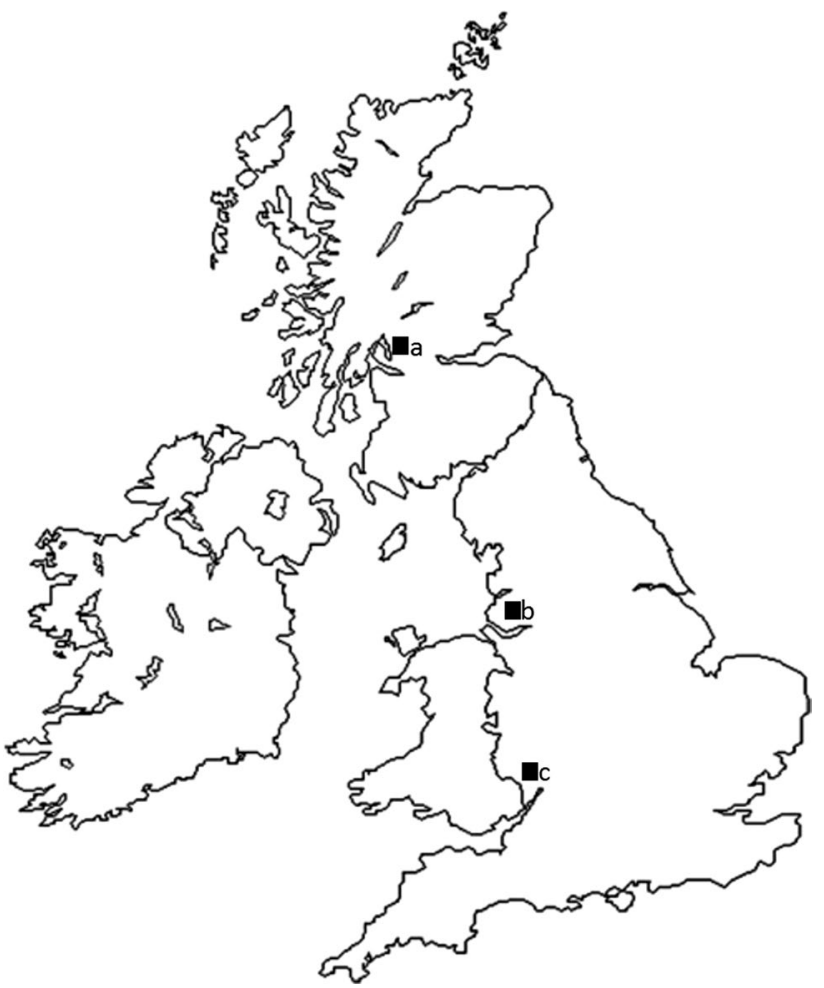

Fig. 1 Geographical representation of the study sites. a Scottish Centre for Ecology and the natural Environment, b North West sites (Ruff Wood, Scutchers Acres, Gorse Hill Nature Reserve, Mere Sands Wood Nature Reserve) within a 7-km radius, c Nagshead Nature Reserve

were in North West UK (see Fig. 1), but the total study area covered a north-south range of $500 \mathrm{~km}$. A description of each site is given in Table 1.

\section{Field sampling}

Nest boxes were observed to determine breeding activity, and bacterial samples taken under Natural England licence (2014/SCI/0288) at the completion of nest building, clutch completion and immediately post fledging.

Data were collected on clutch size, number of young to hatch and number of young to fledge. Data from the Scottish Centre for Ecology and the Natural Environment (SCENE) and Nagshead Nature Reserve was obtained from weekly nest box inspections already in place as part of their management. For all other sites, clutch size was determined from observation at the clutch completion sampling time point of the number of eggs present and whether they were warm, and therefore undergoing incubation, or cold, indicating the clutch had yet to be completed. Hatching and fledging success were calculated once the young had fledged from the observation of any unhatched eggs and deceased nestlings within the nest box. 
Table 1 Study site location, description and nest box status

\begin{tabular}{|c|c|c|c|}
\hline Site & Map reference & Vegetation type & Nest boxes \\
\hline Ruff Wood & $53^{\circ} 33^{\prime} 36.27^{\prime \prime} \mathrm{N}, 002^{\circ} 51^{\prime} 59.43^{\prime \prime} \mathrm{W}$ & Mixed deciduous woodland & $\begin{array}{l}\text { None present, } 20 \text { placed for this } \\
\text { study }\end{array}$ \\
\hline Scutchers Acres & $53^{\circ} 35^{\prime} 17.68^{\prime \prime} \mathrm{N}, 002^{\circ} 49^{\prime} 23.79^{\prime \prime} \mathrm{W}$ & $\begin{array}{l}\text { Mixed deciduous and coniferous } \\
\text { woodland }\end{array}$ & $\begin{array}{l}\text { None present, } 20 \text { placed for this } \\
\text { study }\end{array}$ \\
\hline Gorse Hill Nature Reserve & $53^{\circ} 33^{\prime} 41.45^{\prime \prime} \mathrm{N}, 002^{\circ} 54^{\prime} 53.46^{\prime \prime} \mathrm{W}$ & $\begin{array}{l}\text { Mosaic of woodland, grassland } \\
\text { and arable land }\end{array}$ & $\begin{array}{l}\text { Present, some monitoring from local } \\
\text { volunteer groups }\end{array}$ \\
\hline Mere Sands Wood Nature Reserve & $53^{\circ} 38^{\prime} 05.59^{\prime \prime} \mathrm{N}, 002^{\circ} 50^{\prime} 16.06^{\prime \prime} \mathrm{W}$ & Mixed deciduous woodland & $\begin{array}{l}\text { Present, some monitoring from local } \\
\text { volunteer groups }\end{array}$ \\
\hline $\begin{array}{l}\text { Scottish Centre for Ecology and } \\
\text { the Natural Environment }\end{array}$ & $56^{\circ} 07^{\prime} 13.72^{\prime \prime} \mathrm{N}, 004^{\circ} 35^{\prime} 34.70^{\prime \prime} \mathrm{W}$ & $\begin{array}{l}\text { Oak dominated deciduous wood- } \\
\text { land }\end{array}$ & $\begin{array}{l}500 \text { present, managed by Glasgow } \\
\text { University }\end{array}$ \\
\hline Nagshead Nature Reserve & $51^{\circ} 46^{\prime} 25.59^{\prime \prime} \mathrm{N}, 002^{\circ} 34^{\prime} 20.76^{\prime \prime} \mathrm{W}$ & $\begin{array}{l}\text { Oak dominated deciduous wood- } \\
\text { land }\end{array}$ & $\begin{array}{l}400 \text { present, managed by Royal } \\
\text { Society for the Protection of Birds }\end{array}$ \\
\hline
\end{tabular}

Sterile cotton-tipped swabs (Fisherbrand cat. no. 11552483; Fisher Scientific Int. Inc., Hampton, NH, USA) were pre-moistened in phosphate buffer ( $\mathrm{pH} 7.1,0.2 \mathrm{M})$, and the nesting material was swabbed for $30 \mathrm{~s}$ by the same person in a uniform pattern with particular effort to keep this process standardised and remove inter-operational variability. Swabs were stored in individual 15-ml Falcon tubes (cat. no. 525-0150; VWR Inc., Radnor, PA, USA) containing $1 \mathrm{ml}$ of phosphate buffer (0.2 M, pH 7.1). All samples were processed for culturing within 4-6 h.

\section{Bacterial counts}

Bacterial counts of the samples were obtained in the form of colony forming units (CFU) per millilitre using the Miles et al. (1938) method. Samples were vortexed for $5 \mathrm{~s}$ before a series of tenfold dilutions were made to $10^{-5}$ using sterile phosphate buffer. Samples were plated onto (1) nutrient agar (cat. no. CM0309; Oxoid, Thermo Fisher Scientific, Waltham, MA, USA) to achieve an overall count of culturable bacteria, (2) Baird Parker agar (cat. no. CM0275; Oxoid) with the addition of Egg Yolk Tellurite (cat. no. SR0054; Oxoid) to select for Staphylococcus spp. and (3) Eosin Methylene Blue agar (cat. no. CM0069; Oxoid) to select for Enterobacter spp., across the 3 sample years. Additionally, in 2016, MacConkey agar (cat. no. 0007; Oxoid) was utilised to select for E. coli, and Soya Flour-Mannitol (20 g soya flour, $20 \mathrm{~g}$ mannitol, $20 \mathrm{~g}$ agar per 11 tap water) with the addition of $1 \mathrm{ml}$ nalidixic acid $(25 \mathrm{mg} / \mathrm{ml})$ and $1 \mathrm{ml}$ nystatin/ dimethyl sulfoxide solution $(5 \mathrm{mg} / \mathrm{ml})$ incubated at $25{ }^{\circ} \mathrm{C}$ was utilised to determine the presence of any Actinomycetes. Agar plates were divided into six sections and labelled $10^{-0}-10^{-5}$, respectively, before being placed in a drying cabinet for $1 \mathrm{~h}$. Three $20-\mu \mathrm{l}$ drops of each dilution were pipetted onto the relevant section of the agar to serve as triplicate repeats, and the plates were kept upright for $30 \mathrm{~min}$ to allow the samples to be absorbed and then inverted and incubated for $48( \pm 2) \mathrm{h}$ at $37^{\circ} \mathrm{C}$ according to Mennerat et al. (2009) and Gonzalez-Braojos et al. (2012a, b). Each section was observed for growth; the first dilution showed discrete individual colonies that were counted and recorded. The mean of the triplicate colony counts within the countable dilution was obtained and the CFU per millilitre calculated.

\section{Statistical analysis}

Nonparametric analyses were utilised due to the absence of normal data, even after transformation using $\log (x+1)$. Analysis was undertaken using $\mathrm{R}$ version 3.2.3 (R Core Development Team; RStudio, 2017). A Kruskal-Wallace test with a post hoc Tukey was used to determine any difference in bacterial load at the three sample points. Analysis of egg mortality and chick mortality was heavily skewed by $0 \%$ occurrence in both instances, and although a significant correlation was found in some instances, scatter plots revealed there was no clear relationship between bacterial counts and either egg or chick mortality. The data were therefore converted binomially to give any occurrence of egg/chick mortality a value of 1 and no occurrence a value of 0 . Spearman's rank correlation followed by binomial regression was then performed to determine any significant relationship. To determine any relationship between bacterial load and brood size, we used Spearman's rank correlation followed by Poisson regression analysis.

\section{Results}

Total bacterial counts (CFU/ml) across the nest building and clutch completion stages were not significantly different (Fig. 2a). There was a slight decrease in median bacterial counts upon egg incubation, but variation within nests was higher at this stage. The bacterial count had greatly 
(a) Total count (Nutrient agar)

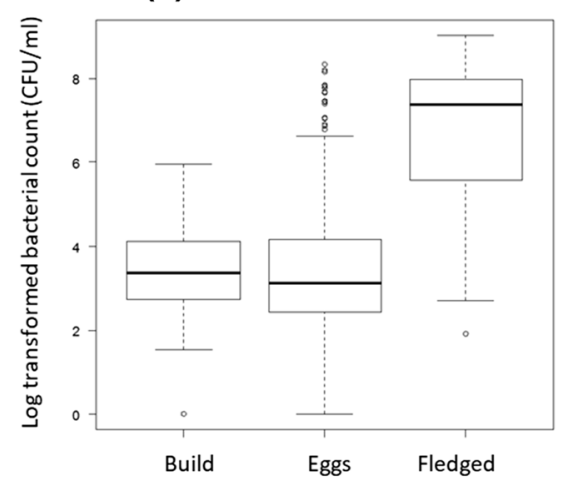

(d) E. coli (MacConkey agar agar)

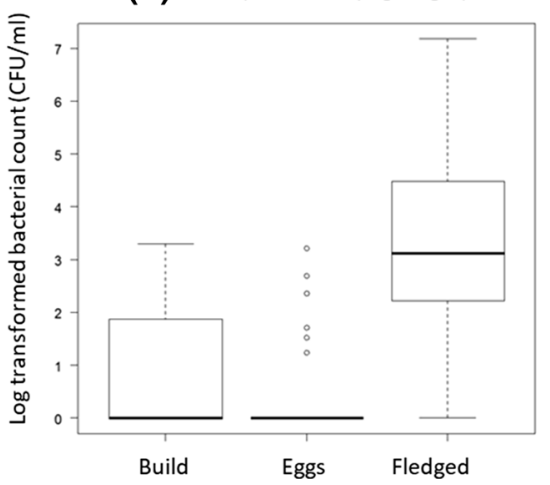

(b) Staphylococci spp. (Baird Parker agar)

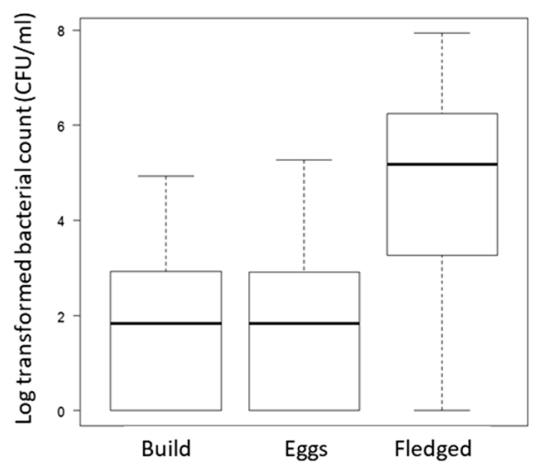

(e) Total count at $25^{\circ} \mathrm{C}$ (Soya flour mannitol agar)

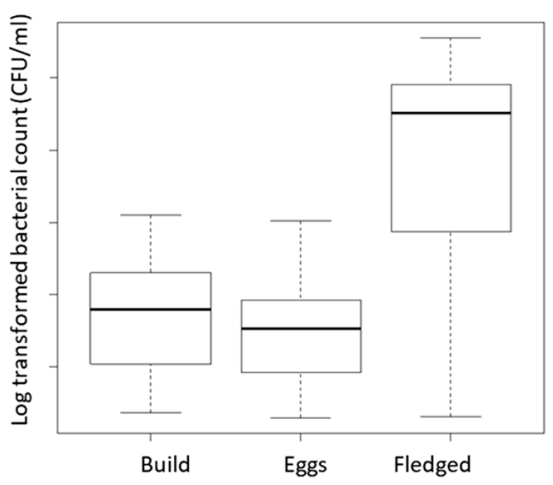

(c) Enterococci spp. (Eosin methylene blue agar)

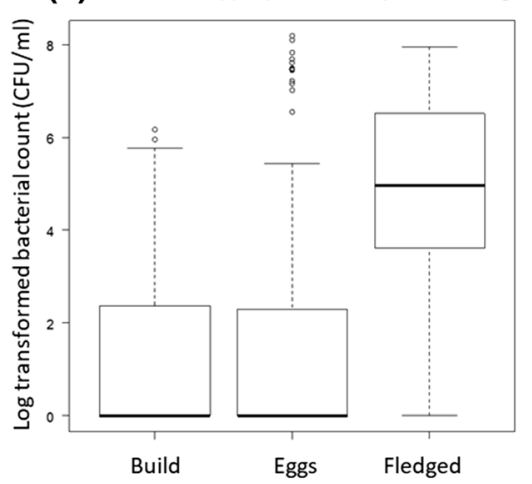

Fledged

Build

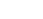

Fig. 2 Bacterial counts (colony-forming units $[\mathrm{CFU}] / \mathrm{ml}$ ) following the culture of swabs of nesting material in nest boxes of the Blue Tit Cyanistes caeruleus taken at three stages of nesting (completion of nest building [Build], clutch completion [Egg] and post fledging [Fledged]). Data are presented as the median $\pm 95 \%$ confidence interval. a Number of bacteria in samples cultured on nutrient agar at the three stages of nesting. The difference between the Build and Egg stages was not significant $(p=0.88)$; significant differences were found between the Build and Fledged stages $(p<0.001)$ and between the Egg and Fledged stages $(p<0.001) ; n=434$. b Number of Staphylococcus species in samples cultured on Baird Parker agar at the three stages of nesting. The difference between the Build and Egg stages was not significant $(p=1)$; significant differences were found between the Build and Fledged stages $(p<0.001)$ and between the Egg and Fledged stages $(p<0.001) ; n=474$. c Number of Enterobacter spe- cies in samples cultured on Eosin Methylene Blue agar at the three stages of nesting. The difference between the Build and Egg stages was not significant $(p=0.79)$; significant differences were found between the Build and Fledged stages $(p<0.001)$ and between the Egg and Fledged stages $(p<0.001) ; n=426$. d Number of Escherichia coli in samples cultured on MacConkey agar at the three stages of nesting. The difference between the Build and Egg stages was not significant $(p=0.11)$; significant differences were found between the Build and Fledged stages $(p<0.001)$ and between the Egg and Fledged stages $(p<0.001) ; n=426$. e Number of bacteria (when incubated at $25{ }^{\circ} \mathrm{C}$ ) in samples cultured on Soya Flour mannitol agar at the three stages of nesting. The difference between the Build and Egg stages was not significant $(p=0.59)$; significant differences were found between the Build and Fledged stages $(p<0.001)$ and between the Egg and Fledged stages $(p<0.001) ; n=426$ increased at the post fledging sample point and was highly significantly different from the values at the earlier sampling points $(p<0.001)$.

Bacterial counts for Staphylococcus spp. (Fig. 2b) showed very little difference between the completion of nest building and clutch completion ( $p=1)$, and at both stages no Staphylococcus spp. were detected in $37 \%$ of nest. Post fledging this dropped to $13 \%$, and there were significantly higher bacterial counts $(p<0.001)$.

Bacterial counts for Enterobacter spp. (Fig. 2c) similarly showed little difference between the completion of nest building and clutch completion stages. At the nest building $63 \%$ of nests had no Enterobacter spp. present, falling to $55 \%$ at clutch completion. Post fledging, $79 \%$ of nest had Enterobacter spp. present, and there were significantly higher bacterial counts $(p<0.001)$.

Bacterial counts for E. coli (Fig. 2d) were the lowest across the selective agars utilised in our study, with $E$. coli detected in only $47 \%$ of nests at nest completion, $18 \%$ of nests at clutch completion and $81 \%$ of nests post fledging. There was little change in bacterial counts between nest completion and clutch completion; however, bacterial counts post fledging were significantly higher $(p<0.001)$. The highest bacterial counts obtained on Soya Flour mannitol agar were for the nest and clutch completion stages, respectively, and bacterial counts were present in all nests 
across all stages (Fig. 2e). Counts between the nest and clutch completion stages were not significantly different $(p=0.59)$, but they did increase greatly at the post fledging stage $(p<0.001)$. Bacterial counts between nests varied greatly across all five agars.

The total bacterial count on nutrient agar and egg mortality were significantly negatively correlated $\left(r_{\mathrm{s}}=-0.25\right.$, $p<0.001, n=108)$, with binomial regression also showing significance $(z=-2.058, p=0.040, d f=1,106) ; 12.75 \%$ of egg mortalities were explained by the model. Neither Staphylococcus spp. counts $\left(r_{\mathrm{s}}=0.18, p=0.85, n=111\right)$, Enterobacter $\mathrm{spp}$. counts $\left(r_{\mathrm{s}}=-0.04, p=0.66, n=111\right), E$. coli counts $\left(r_{\mathrm{s}}=-0.15, p=0.40, n=111\right)$ nor the total count on Soya Flour Mannitol agar $\left(r_{\mathrm{s}}=-0.11, p=0.55, n=111\right)$ showed significance with egg mortality.

No relationship between bacterial counts and chick mortality was noted on either non-selective or selective agars (total count on nutrient agar: $r_{\mathrm{s}}=0.07, p=0.50, n=111$ ); Staphylococcus spp.: $r_{\mathrm{s}}=0.16, p=0.09, n=111$; Enterobacter spp.: $r_{\mathrm{s}}=0.13, p=0.18, n=111 ;$ E. coli: $r_{\mathrm{s}}=-0.15$, $p=0.40, n=32$; Soya Flour mannitol agar: $r_{\mathrm{s}}=-0.11$, $p=0.55, n=32$. Brood size had no significant relationship with either the total bacterial count on nutrient agar $\left(r_{\mathrm{s}}=0.02, p=0.83, n=111\right)$, Staphylococcus spp. $\left(r_{\mathrm{s}}=0.12\right.$, $p=0.21, n=111)$, Enterobacter $\mathrm{spp} .\left(r_{\mathrm{s}}=0.009, p=0.93\right.$, $n=111)$, E. coli $\left(r_{\mathrm{s}}=0.15, p=0.40, n=32\right)$ or Soya Flour mannitol agar $\left(r_{\mathrm{s}}=-0.16, p=0.37, n=32\right)$.

\section{Discussion}

The main result of this study is the significantly higher number of bacteria in the nests at the fledged stage compared to all other stages, with a minimal difference between the completion of nest building and clutch completion. A significant negative correlation between the total bacterial count on nutrient agar and egg mortality was also identified. Although the total bacterial load showed only a minimal difference between nest completion and clutch completion, there was a marked increase in the variation of counts between nests upon the initiation of incubation. The bacterial load of Staphylococcus spp. and Enterobacter spp. followed a similar pattern. In the process of laying eggs, bacteria from the female's cloacal cavity are introduced into the nest; of these bacteria, Enterobacter spp. and Coliform spp. have been found to be prevalent (Sanders et al. 2005). Upon incubation, the temperature of the nest cup and the eggs rises to between 35 and $38{ }^{\circ} \mathrm{C}$ (Nord and Nilsson 2011); this temperature range is closely related to the body temperature of the adult birds and as such the optimum temperature for hostassociated bacteria. These findings lead to the expectation that the bacterial load would increase significantly with this increase in ambient temperature compared with the bacterial load at the earlier ambient temperature. However this was not the case in our study. Possible explanations could include a lack of nutrients to facilitate growth or that the swabs were taken before the bacteria had sufficient time to benefit from the improved conditions. The significantly higher bacterial loads for total, Staphylococcus spp. and Enterobacter spp. is mainly associated with the increased activity within the nest. Both parents are continually bringing food to the nest, leaving little time for preening and nest sanitation; thus, the removal of faecal sacs before the protective mucous covering deteriorates becomes less achievable The food itself and nestling faeces also provide a constant source of bacteria. Benskin et al. (2015) analysed C. caeruleus faeces and found 55 bacterial operational taxonomic units. Although these authors did not investigate bacterial loads, their study illustrates the high diversity of bacterial communities in the faeces.

Egg mortality showed a significant negative relationship with total bacterial counts at clutch completion, with bacterial counts increasing with decreasing egg mortality. This result was somewhat unexpected. One possible explanation is based on the removal of belly feathers by the female prior to incubation to aid in efficient temperature transfer to the eggs (Nord and Nilsson 2011). These feathers are then used as lining material in the nest cup. Uropygial oil from the preening process will still be present on these feathers (Peralta-Sanchez et al. 2012), thus providing a community of beneficial bacteria that aid in the control of pathogenic bacteria. In terms of competition, these symbiotic bacteria are generally superior to their pathogenic counterparts (Brook 1999) due to co-evolutionary interactions between host and microorganism (Hackstein and van Alen 1996), bacterial interference through the production of antibiotic substances to impede the establishment of competing bacteria (Riley and Wertz 2002) and/or modification of the environment by the host for symbiotic bacteria (Hackstein et al. 1996). Although the bacterial load increases, this increase likely benefits the eggs by protecting them from possible pathogens.

No relationship was found between the load of Staphylococcus spp., E. coli or Enterobacter spp. with egg mortality, despite E. coli and S. epidermitis being associated with egg mortality in sparrow nests (Pinowski et al. 1994). Pathogenic bacteria present on the egg need to travel through pores in the shell before they can infect the embryo. This process is heavily dependent on the presence of water, and a major benefit to nest boxes over natural cavities is the increased waterproofing of the former. Nest boxes are more prone to condensation, but this is offset by the maintenance of a warm incubation temperature (D'Alba et al. 2010). Antimicrobials present within the egg white provide additional defence 
against any bacteria that are able to breach the shell, thereby protecting the embryo.

Analysis of the data revealed the absence of a relationship between chick mortality and any of the bacterial counts, thereby supporting the results of Berger et al. (2003). Nestlings are exposed to many potential mortality factors, of which bacterial load and type of bacterial community are likely to be minor ones. Significant mortality factors include nutrition (Gonzalez-Braojos et al. 2012b) and ectoparasite load (Richner et al. 1993). A more prominent relationship with bacterial load may be a measure of nestling fitness. Benskin et al. (2015) found that Bacillus licheniformis was the most prevalent bacteria species among isolates, being detected in nearly $75 \%$ of all C. caeruleus faecal samples. B. licheniformis can be a feather-degrading bacteria, possibly influencing feather condition and coloration (Gunderson 2008). A reduction in feather quality has a detrimental effect on thermoregulation and flight, and any change in coloration can affect mate choice. Feather-degrading bacteria are transient within the nest environment, with those isolated on the feathers of parents subsequently found in the cloaca of nestlings (Giraudeau et al. 2010).

No relationship was discovered between brood size and bacterial counts, which is counter to the results of several previous studies (Lucas et al. 2005; Gonzalez-Braojos et al. 2012a, b, 2015; Cantarero et al. 2013; Alt et al. 2015). However these earlier studies focussed on plumage bacteria sampled from the feathers of the birds. Among these plumage bacteria, attached bacteria are less likely to be found on the nesting material, and although freeliving plumage bacteria have been shown to be transient and could be present in nesting material, they may have little effect on the bacterial load of the nesting material.

In conclusion, we found that bacterial counts increase significantly upon the hatching of the eggs and that, consequently, the chicks are exposed to potentially pathogenic bacteria. However, exposure to these bacteria was found to have no detrimental effect on egg or chick mortality. The culture of swabs of nesting material on selective agars only provides an indication of the presence of a species within the selected genus; therefore, the pathogenic species may not be present. Although bacterial load is a useful indicator of the pressures faced by the chicks in their first stage of life, the next step is to investigate the bacterial diversity at each stage of the breeding process and to identify the bacteria present within the nest box.

Acknowledgements The authors would like to thank site owners/ managers for site access and the Scottish Centre for Ecology and the Natural Environment and Nagshead Nature Reserve for supplying data on Blue Tit nesting activity. This experiment complies with the current laws of the country in which they were performed.

\section{Compliance with ethical standards}

Ethical approval All applicable international, national, and/or institutional guidelines for the care and use of animals were followed. All procedures performed in studies involving animals were in accordance with the ethical standards of the institution or practice at which the studies were conducted.

Open Access This article is distributed under the terms of the Creative Commons Attribution 4.0 International License (http://creativeco mmons.org/licenses/by/4.0/), which permits unrestricted use, distribution, and reproduction in any medium, provided you give appropriate credit to the original author(s) and the source, provide a link to the Creative Commons license, and indicate if changes were made.

\section{References}

Alt G, Saag P, Magi M, Kisand V, Mand R (2015) Manipulation of parental effort affects plumage bacterial load in a wild passerine. Oecologia 178:451-459. https://doi.org/10.1007/s0044 2-015-3238-1

Benskin C, Rhodes G, Pickup R, Mainwaring M, Wilson K, Hartley I (2015) Life history correlates of fecal bacterial species richness in a wild population of the Blue Tit Cyanistes caeruleus. Ecol Evol 5(4):821-836. https://doi.org/10.1002/ece3.1384

Berger S, Disko R, Gwinner H (2003) Bacteria in starling nests. J Ornithol 144(3):317-322. https://doi.org/10.1007/BF02465631

Brook I (1999) Bacterial interference. Crit Rev Microbiol 25:155-172. https://doi.org/10.1080/10408419991299211

Cantarero A, Lopez-Arrabe J, Rodriguez-Garcia V (2013) Factors affecting the presence and abundance of generalist ectoparasites in the nests of three sympatric hole-nesting bird species. Acta Ornithol 48(1):39-54. https://doi.org/10.3161/000164513X669982

D'Alba L, Oborn A, Shawkey D (2010) Experimental evidence that keeping eggs dry is a mechanism for the antimicrobial effects of avian incubation. Naturwissenschaften 97:1089-1095. https://doi. org/10.1007/s00114-010-0735-2

Dawson RD (2004) Does fresh vegetation protect avian nests from ectoparasites? An experiment with tree swallows. Can J Zool 82(7):1005-1010. https://doi.org/10.1139/Z04-076

Giraudeau M, Czirjak G, Duval C (2010) Effect of restricted preengland access on maternal maintenance and reproductive investment in mallards. PLoS One 5(10):1-7. https://doi.org/10.1371/ journal.pone.0013555

Gonzalez-Braojos S, Vela A, Ruiz-de-Castaneda R, Briones V, Cantarero A, Moreno J (2012a) Is nestling growth affected by nest reuse and skin bacteria in pied flycatchers Ficedula hypoleuca? Acta Ornithol 47(2):119-127. https://doi.org/10.3161/000164512X 662223

Gonzalez-Braojos S, Vela A, Ruiz-de-Castaneda R, Briones V, Moreno J (2012b) Sources of variation in enterococci and Enterobacteriaceae loads in nestlings of a hole-nesting passerine. Ardea 100:71-77. https://doi.org/10.5253/078.100.0111

Gonzalez-Braojos S, Vela A, Ruiz-de-Castaneda R, Briones V, Cantarero A, Moreno J (2015) Bacteria on nestling skin in relation to growth in pied flycatchers. J Ornithol 156:327-330. https://doi. org/10.1007/s 10336-014-1100-6

Goodenough AE, Hart AG (2011) Microbiology of bird nest boxes. Microbiologist 12:28-31

Goodenough AE, Stallwood B (2010) Intraspecific variation and interspecific differences in the bacterial and fungal assemblages 
of Blue Tit (Cyanistes caeruleus) and Great Tit (Parus major) nests. Microb Ecol 59(2):221-232. https://doi.org/10.1007/s0024 8-009-9591-z

Goodenough AE, Stallwood B (2012) Differences in culturable microbial communities in bird nest boxes according to orientation and influences on offspring quality in Great Tits (Parus major). Microb Ecol 63(4):986-995. https://doi.org/10.1007/s0024 8-011-9992-7

Gunderson A (2008) Feather-degrading bacteria: a new frontier in avian and host-parasite research? Auk 125(4):972-979. https:// doi.org/10.1525/auk.2008.91008

Gwinner H, Berger S (2005) European starlings: nestling condition, parasites and green nest material during the breeding season. J Ornithol 146(4):365-371. https://doi.org/10.1007/s1033 6-005-0012-x

Hackstein JHP, van Alen TA (1996) Fecal methanogens and vertebrate evolution. Evolution 50:559-572. https://doi.org/10.2307/24108 31

Hackstein JHP, Langer P, Rosenberg J (1996) Genetic and evolutionary constraints for the symbiosis between animals and methanogenic bacteria. Environ Monit Assess 42:39-56. https://doi.org/10.1007/ BF00394041

Hebda G, Wesolowski T (2012) Brief report low flea loads in bird's nests in tree cavities. Ornis Fennica 89:139-144

Ibanez-Alamo J, Ruiz-Rodriguez M, Soler J (2014) The mucous covering of fecal sacs prevents birds from infection with enteric bacteria. J Avian Biol 45:354-358. https://doi.org/10.1111/jav.00353

Ichida J, Krizova L, LeFervre C, Keener H, Elwell D, Burtt E (2001) Bacterial inoculum enhances keratin degradation and biofilm formation in poultry compost. J Microbiol Methods 47:199-208. https://doi.org/10.1016/S0167-7012(01)00302-5

International Union for Conservation of Nature (IUCN) (2016) The IUCN Red List of threatened species.http://www.iucnredlist.org/ search. Accessed 23 Feb 2016

Kilgas P, Saag P, Magi M, Tilgar V, Mand R (2012) Plumage bacterial load increases during nest-building in a passerine bird. J Ornithol 153:833-838. https://doi.org/10.1007/s10336-011-0801-3

Lucas F, Moureau B, Jourdie V, Heeb P (2005) Brood size modifications affect plumage bacteria assemblages of European starlings. Mol Ecol 14:639-646. https://doi.org/10.1111/j.1365294x.2005.02436.x

Martin-Vivaldi M, Ruiz-Rodriguez M, Soler J, Peralta-Sanchez M, Mendez M, Valdivia E, Martin-Platero A, Martinez-Bueno M (2009) Seasonal, sexual and developmental differences in hoopoe Upupa epops preen gland morphology and secretions: evidence for a role of bacteria. J Avian Biol 40:191-205. https://doi. org/10.1111/j.1600-048X.2009.04393.x

Mennerat A, Mirleau P, Blondel J, Perret P, Lambrechts M, Heeb P (2009) Aromatic plants in the nests of the Blue Tit Cyanistes caeruleus protect chicks from bacteria. Oecologia 161:849-855. https://doi.org/10.1007/s00442-009-1418-6

Miles A, Misra S, Irwin J (1938) The estimation of the bactericidal power of the blood. J Hyg (Lond) 38(06):732-749

Mills T, Lombardo M, Thorpe P (1999) Microbial colonization of the cloacae of nestling tree swallows. Auk 116(4):947-956. https:// doi.org/10.2307/4089674

Moller A, Peralta-Sanchez J, Nielsen J, Lopez-Hernandez E, Soler J (2012) Goshawk prey have more bacteria than non-prey. J Anim Ecol 81:403-410. https://doi.org/10.111 1/j.1365-2656.2011.01923.x

Moreno J, Merino S, Lobato E, Ruiz-De-Castaneda R, La Puente JM, Del Cerro S, Aguilar JR (2009) Nest-dwelling ectoparasites of two sympatric hole-nesting passerines in relation to nest composition: an experimental study. Ecoscience 16(3):418-427. https:// doi.org/10.2980/16-3-3233

Newton I (1994) The role of nest sites in limiting the numbers of holenesting birds: a review. Biol Conserv 70(3):265-276. https://doi. org/10.1016/0006-3207(94)90172-4

Nord A, Nilsson J (2011) Incubation temperature affects growth and energy metabolism in Blue Tit nestlings. Am Nat 178(5):639-651. https://doi.org/10.1086/662172

Peralta-Sanchez J, Martin-Vivaldi M, Martin-Platero A, MartinezBueno M, Onate M, Ruiz-Rodriguez M, Soler J (2012) Avian life history traits influence eggshell bacterial loads: a comparative analysis. Ibis 154:725-737. https://doi.org/10.1111/j.1474919X.2012.01256.X

Pinowski J, Barkowska M, Kruszewicz AH, Kruszewicz AG (1994) The causes of the mortality of eggs and nestlings of Passer spp. J Biosci 19(4):441-451. https://doi.org/10.1007/BF02703180

RStudio Team (2017) RStudio: Integrated Development for R. RStudio Inc, Boston, MA. http://www.rstudio.com/

Richner H, Oppliger A, Christe P (1993) Effect of an ectoparasite on reproduction in Great Tits. J Anim Ecol 62:703-710. https://doi. org/10.2307/5390

Riley MA, Wertz JE (2002) Bacteriocines: evolution, ecology, and application. Annu Rev Microbiol 56:117-137. https://doi. org/10.1146/annurev.micro.56.012302.161024

Royal Society for the Protection of Birds (RSPB) (2016) Blue Tit.http:// www.rspb.org.uk/discoverandenjoynature/discoverandlearn/birdg uide/name/b/bluetit/index.aspx. Accessed 23 Feb 2016

Sanders B, Arega F, Sutula M (2005) Modelling the dry-weather tidal cycling of fecal indicator bacteria in surface waters of an intertidal wetland. Water Res 39(14):3394-3408. https://doi.org/10.1016/j. watres.2005.06.004

Shawkey M, Firestone M, Brodie E, Beissinger S (2009) Avian incubation inhibits growth and diversification of bacterial assemblages on eggs. PLoS One 4(2):e4522. https://doi.org/10.1371/journ al.pone. 0004522

Soler J, Martin-Vivaldi M, Ruiz-Rodriguez M, Valdivia E, martin-Platero A, Martinez-Bueno M, Peralta-Sanchez J, Mendez M (2008) Symbiotic association between hoopoes and antibiotic-producing bacteria that live in their uropygial gland. Funct Ecol 22:864-871. https://doi.org/10.1111/j.1365-2435.2008.01448.x

Soler J, Peralta-Sanchez J, Martin-Platero A, Martin-Vivaldi M, Martinez-Bueno M, Moller A (2012) The evolution of the size of the uropygial gland: mutualistic feather mites and uropygial secretion reduce bacterial loads of eggshells and hatching failures of European birds. J Evol Biol 25:1779-1791. https://doi.org/10.11 11/j.1420-9101.2012.02561.x

Wesolowski T, Rowinski P (2012) The breeding performance of Blue Tits Cyanistes caeruleus in relation to the attributes of natural holes in a primeval forest. Bird Study 59(4):437-448. https://doi. org/10.1080/00063657.2012.722189 


\section{Affiliations}

\section{Andrew Devaynes $^{1}\left[\right.$. André Antunes $^{1} \cdot$ Alan Bedford $^{1} \cdot$ Paul Ashton $^{1}$}

$\triangle$ Andrew Devaynes

devaynea@edgehill.ac.uk

1 Edge Hill University, Ormskirk, Lancashire L39 4QP, UK 